\title{
The Third Head of the Biceps Brachii Muscle Perforated by the Musculocutaneous Nerve
}

\author{
La Tercera Cabeza del Músculo Bíceps Braquial Perforada por el Nervio Musculocutáneo
}

\author{
Ji-Hoon Jang ${ }^{1, *}$; Jae-Ho Lee ${ }^{2, *}$ \& Joo-Young Kim¹
}

JANG, J. H.; LEE, J. H. \& KIM, J. Y. The third head of the biceps brachii muscle perforated by the musculocutaneous nerve. Int. J. Morphol., 37(4):1226-1228, 2019.

SUMMARY: During an educational dissection, the third head of the biceps brachii muscle was found on the left side in a 63-yearold female Korean cadaver. The short and long heads showed normal morphology, and their courses were as follows: The third head was originated from the middle level of the humerus under the short head and inserted in the conjoined tendon of the long and short heads of the biceps brachii muscle. The musculocutaneous nerve penetrated the third head of the biceps brachii muscle and became the lateral cutaneous nerve of the forearm. The authors describe this novel case and discuss the clinical implications of such a variation.

KEY WORDS: Biceps brachii muscle; Musculocutaneous nerve; Third head; Variation.

\section{INTRODUCTION}

The biceps brachii muscle (BBM) has two heads, a long head originating from the supraglenoid tubercle and a short head originating from the coracoid process of the scapula. In terms of the number and morphology of its heads, the BBM is one of the most variable muscles in the human body (Rodríguez-Niedenführ et al., 2003). The most common variation is a third head, but four, five, or even seven heads have been reported (Asvat et al., 1993; Nakatani et al., 1998). The presence of the third head has been reported with varying frequency from $8 \%$ to $37.5 \%$ depending on the population (Asvat et al.; Rincón et al., 2001; Standring, 2016). This supernumerary muscle has clinical importance because it may cause the compression of neurovascular structures or confuse a surgeon who performs procedures on the arm (Warner et al., 1992). In this case, we report a unique morphology of the third head of the BBM and discuss the clinical significance of this variation.

\section{CASE REPORT}

During a routine dissection of the upper limb, variation of the BBM was found on the left side of a 63year-old female cadaver. After the skin, subcutaneous fat, and fascia were removed to expose the BBM, the nerve and blood supply of each head were carefully examined. The findings were photographed, and the length and width of the muscle were measured in millimeters. The long and short heads of the BBM were originated from the supraglenoid tubercle and the coracoid process of the scapula, respectively. At the middle level of the humerus, a thin accessory muscle was originated as the third head of the BBM and continued $114 \mathrm{~mm}$ more under the short head of the BBM (Fig. 1A). It merged to the combined tendon of the BBM. The musculocutaneous nerve perforated the coracobrachialis muscle and gave off the branches for the long and short heads of BBM (Fig. 1B). Then, it penetrated the third head of the BBM obliquely and became the lateral cutaneous nerve of the forearm. No variation was observed in the other neurovascular structures.

\section{DISCUSSION}

The BBM exhibits a wide array of variable morphological characteristics (Asvat et al.; Nakatani et al.; Rincón et al.; Rodríguez-Niedenführ et al.; Standring). In detail, the prevalence rates of supernumerary heads of the BBM are as follows: Chinese, $8 \%$; European whites, 10 $\%$; African blacks, $12 \%$; Japanese, $18 \%$; South African blacks, $20.5 \%$; South African whites, $8.3 \%$; and

\footnotetext{
${ }^{1}$ Department of Anatomy, Yeungnam University College of Medicine, Daegu, Republic of Korea.

${ }^{2}$ Department of Anatomy, Keimyung University School of Medicine, Daegu, Republic of Korea.

* These authors contributed equally to this work.
} 
Colombian, $37.5 \%$ (Asvat et al.; Nakatani et al.; Rincón et al.; Standring). Lee (2013) are found this variation in 14 of $214(6.5 \%)$ individuals in the Korean populations, a lowest prevalence than other populations. They reported that supernumerary head of the BBM occurs unilaterally rather than bilaterally (Asvat et al.; Rincón et al.). Some studies demonstrated that supernumerary heads are more commonly found in males, however, it is controversial until now (Vijayabhaskar et al., 2008).

Rodriguez-Niedenfuhr et al. (2003) classify the type of supernumerary head of the BBM according to its location by dissecting $350 \mathrm{arms}$. The most common type is the inferomedial humeral head ( $9 \%$ ), originating from the humerus at the level of the coracobrachialis insertion or brachialis. The superior humeral head $(1.5 \%)$ is originated from the lesser tubercle, external lip of the bicipital groove, undersurface of the pectoralis major, deltoid muscle, or anterior surface of the shoulder joint capsule. The inferolateral humeral head $(0.9 \%)$ is the least common variation, originating from the lateral intermuscular septum, between the insertion of the deltoid and the origin of the brachioradialis, or from the supracondylar ridge.

On the basis of this criterion, the third head in our case was the inferomedial humeral head, the most frequent type of variation in the BBM. The variant origin, insertion, shape, and number of BBM have been frequently reported still (Asvat et al.; Nakatani et al.; Rincón et al.; RodríguezNiedenführ et al.; Standring). However, the musculocutaneous nerve abruptly pierced the third head of the BBM, and this case has not been reported in any articles.

Embryologically, the mesoderm invades the upper limb bud to further condense into ventral and dorsal muscle masses during the fifth week of development (RodríguezNiedenführ et al.). The biceps musculature is derived from the ventral muscle masses of the upper limb bud. The supernumerary head of the BBM may be originated from the incomplete cleavage of the ventral muscle masses. The development of neurovascular structures also may contribute to the cleavage of these muscles. Especially the inferomedial head was suggested to be due to the musculocutaneous nerve piercing the brachialis muscle and producing a separate head. Therefore, these reasons induced a musculocutaneous nerve penetrating the third head of the BBM, as presented in this report.

Here, we report a third head of the BBM penetrated by the musculocutaneous nerve for the first time. The presence of the third head may cause compression of neurovascular structures and can be easily confused with pathological conditions in CT and MR imaging. Therefore, knowledge of the variations of the BBM is important for clinicians because it increases the incidence of iatrogenic injuries during surgery and invasive procedures (Warner et al.; Vijayabhaskar et al.).

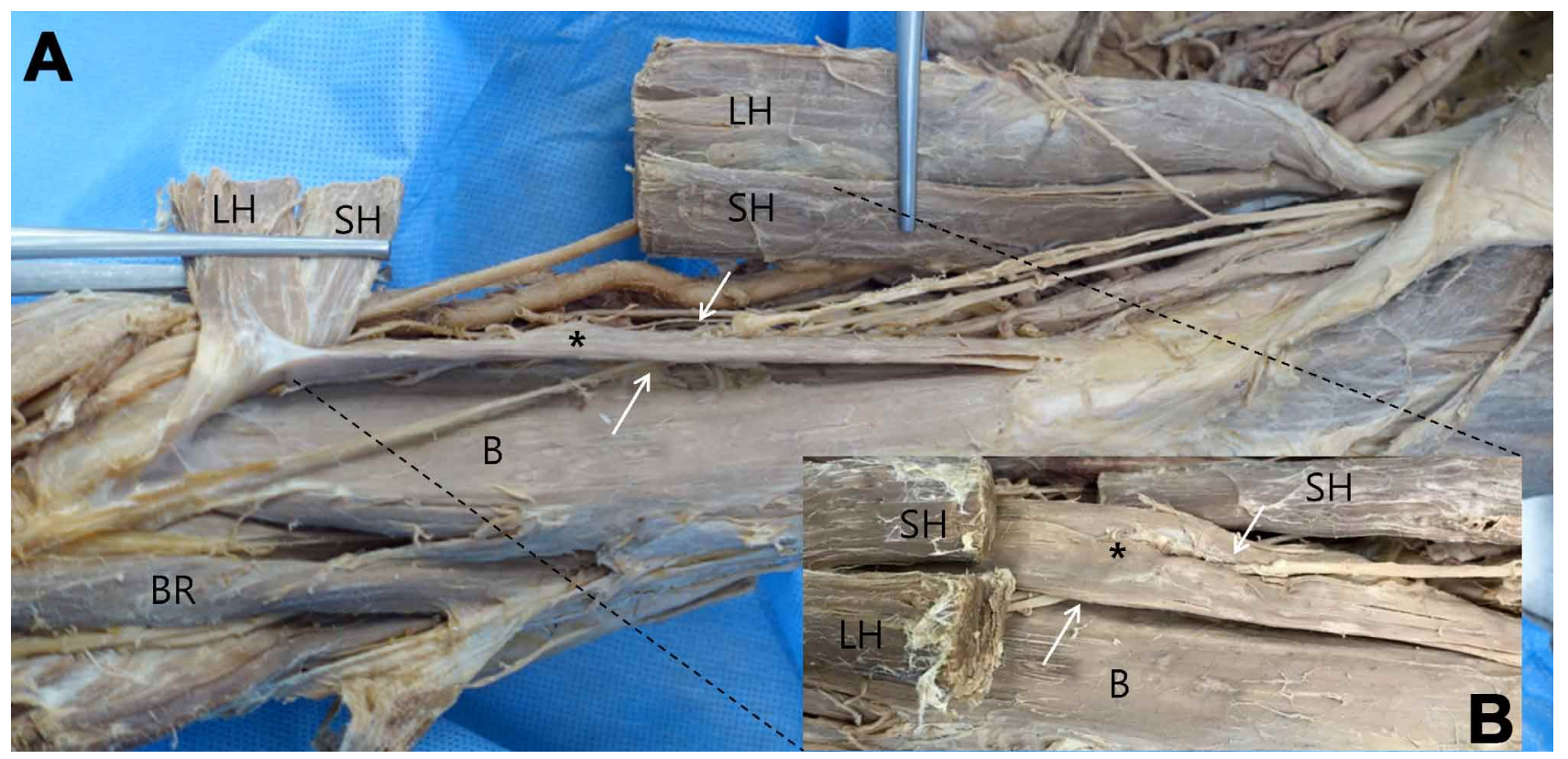

Fig. 1. The third head (*) of the biceps brachii muscle in the left arm. The musculocutaneous nerve perforates the third head (arrows). (A) Anterolateral view (B) superior view. B, brachialis; BR, brachioradialis; LH, long head of biceps brachii muscle; SH, short head of biceps brachii muscle. 
JANG, J. H.; LEE, J. H. \& KIM, J. Y. La tercera cabeza del músculo bíceps braquial perforada por el nervio músculo cutáneo. Int. J. Morphol., 37 (4):1226-1228, 2019.

RESUMEN: Durante una disección educativa, la tercera cabeza del músculo bíceps braquial se encontró en el lado izquierdo en un cadáver coreano de 63 años de edad. La cabeza corta y la cabeza larga mostraron una morfología normal, y se presentaron de la siguiente forma: La tercera cabeza se originó en el nivel medio del húmero, inferior a la cabeza corta, y se insertó en el tendón unido de las cabezas larga y corta del músculo bíceps braquial. El nervio musculocutáneo penetró en la tercera cabeza del músculo bíceps braquial para transformarse en el nervio cutáneo lateral del antebrazo. Los autores describen este nuevo caso y discuten las implicaciones clínicas de esta variación.

PALABRAS CLAVE: Músculo bíceps braquial; Nervio musculocutáneo; Tercera cabeza; Variación.

\section{REFERENCES}

Asvat, R.; Candler, P. \& Sarmiento, E. E. High incidence of the third head of biceps brachii in South African populations. J. Anat., 182(Pt. 1):1014, 1993.

Lee, J. H. The third head of biceps brachii muscle in korean: anatomical study. Korean J. Phys. Anthropol., 26(3):97-100, 2013.

Nakatani, T.; Tanaka, S. \& Mizukami, S. Bilateral four-headed biceps brachii muscles: the median nerve and brachial artery passing through a tunnel formed by a muscle slip from the accessory head. Clin. Anat., 11(3):20912, 1998.

Rincón, F.; Rodríguez, Z. I.; Sánchez, A.; León, A. \& González, L. F. The anatomic characteristics of the third head of biceps branchii muscle in a Colombian population. Rev. Chil. Anat., 20(2):197-200, 2001.

Rodríguez-Niedenführ, M.; Vázquez, T.; Choi, D.; Parkin, I. \& Sañudo, J. R. Supernumerary humeral heads of the biceps brachii muscle revisited. Clin. Anat., 16(3):197-203, 2003.

Standring, S. Graycs Anatomy. The Anatomical Basis of Clinical Practice. $41^{\text {st }}$ ed. New York, Elsevier, 2016.

Vijayabhaskar, P.; Baral, P.; Vaishya, R. \& Shrestha, R. N. Supernumerary head of biceps brachii: a rare occurrence in the Nepalese population. Kathmandu Univ. Med. J. (KUMJ), 6(2):225-7, 2008.

Warner, J. P.; Paletta, G. A. \& Warren, R. F. Accessory head of the biceps brachii. Case report demonstrating clinical relevance. Clin. Orthop. Relat. Res., (280):179-81, 1992.

\section{Corresponding author: Joo-Young Kim Department of Anatomy College of Medicine Yeungnam University 170 Hyeonchung-ro Nam-gu, Daegu 42415 REPUBLIC OF KOREA}

E-mail: jookim@med.yu.ac.kr

Received: 07-08-2018

Accepted: 10-06-2019 